\title{
THE IMPACT OF THE GLOBAL FINANCIAL CRISIS ON DECENTRALIZED GOVERNMENT IN SOUTH AFRICA
}

Nico Steytler et Derek Powell

Centre international de formation européenne | « L'Europe en Formation »

2010/4 n 358 | pages 149 à 172

ISSN 0014-2808

Article disponible en ligne à l'adresse :

https://www.cairn.info/revue-l-europe-en-formation-2010-4-page-149.htm

Distribution électronique Cairn.info pour Centre international de formation européenne.

(c) Centre international de formation européenne. Tous droits réservés pour tous pays.

La reproduction ou représentation de cet article, notamment par photocopie, n'est autorisée que dans les limites des conditions générales d'utilisation du site ou, le cas échéant, des conditions générales de la licence souscrite par votre établissement. Toute autre reproduction ou représentation, en tout ou partie, sous quelque forme et de quelque manière que ce soit, est interdite sauf accord préalable et écrit de l'éditeur, en dehors des cas prévus par la législation en vigueur en France. Il est précisé que son stockage dans une base de données est également interdit. 


\title{
The impact of the global financial crisis on decentralized government in South Africa
}

\author{
Nico Steytler \& Derek Powell
}

Nico Steytler is Professor at the Community Law Centre, University of the Western Cape, South Africa. Derek Powell is Senior Researcher at the Community Law Centre.

\section{INTRODUCTION}

The global financial crisis has had a severe impact on South Africa. ${ }^{1}$ The economy went into recession in 2008/09 for the first time in 17 years. Nearly a million jobs were lost in 2009 alone. Growth has resumed, but the recovery is fragile, and another recession possible. Rising unemployment and poverty have placed greater demands on state resources even as revenues contracted, and there is mounting political pressure on government to review its economic policy.

This paper examines the impact of the global financial crisis on South Africa, in particular on how the highly centralized federal system absorbed and responded to the crisis. We make two arguments: First, the political implications of the crisis are far-reaching. The global crisis and the recession that followed have exacerbated long-standing structural problems in the economy (poverty, unemployment and inequality skewed along racial lines). Political divisions have opened over the right economic policy for the country. The crisis has thus merely deepened an already strong sense of national crisis in a country where 40 per cent of the working age population is unemployed and income inequality is amongst the

1. An early version of this article was presented at the annual conference of the International Association of Centres for Federal Studies / IPSA conference in Philadelphia, USA, 16-18 September 2010. 
highest in the world. ${ }^{2}$ Second, the state's response to the crisis again highlighted the highly centralised nature of the country's fiscal constitution ${ }^{3}$ : The national government spearheaded the country's response to the crisis due to the fact that it has exclusive responsibility for economic and fiscal policy. With the main role of the provincial and local orders being that of implementing national policy, the scope for a differentiated response by individual provincial and local governments was thus limited. The national response sought to protect existing levels of social expenditure while simultaneously stimulating growth and employment through massive public investment in economic infrastructure. This cushioned the impact of the crisis on the provincial and local orders which are responsible for service delivery, but has also reinforced already strong tendencies towards centralization within the federal system.

The paper is divided into three substantive sections. Section two explores the impact of the financial crisis on the economy and the three orders of government (the national, provincial and local spheres of government). Section three examines how each sphere responded to the crisis. Section four assesses the impact of those responses on the political economy of the country and the workings of the federal system, concluding with a speculation on the long term legacy of the global crisis.

\section{THE IMPACT OF THE GLOBAL FINANCIAL CRISIS ON SOUTH AFRICA}

\section{The economic impact}

In early 2007 South Africa's Minister of Finance, Trevor Manuel, felt the sun and was forecasting fair winds for the South African economy over the next three years. ${ }^{4}$ The economy was experiencing its longest period of sustained growth in its history and future growth was projected. Positive employment figures were a riposte to the left's building attacks on government's orthodox macro-economic policy as being a formula for jobless growth serving the interests of the capitalist class. The national revenue service had yet again exceeded its revenue collection targets, and the national government was projecting another year of strong growth in public spending on infrastructure and social services. For the first time since 1994, the national government was budgeting for a modest surplus.

2. For recent study of income inequality and the distribution of poverty see Bhorat, Haroon, 2010, "Income and non-income inequality in post-apartheid South Africa: What are the drivers and possible policy interventions", in Development Policy Research Centre Policy Brief Series, January.

3. Murray, Christina and Simeon, Richard, 2000, "South Africa's financial constitution: towards better delivery", in: SA Public Law 15, 477.

4. Manuel, Trevor, 2007, "Budget Speech: Address by the Minister of Finance to Parliament", 20 February. 
Although the extremely high levels of inequality, poverty and unemployment remained serious problems, the economic indicators suggested that South Africa was starting to pull clear of its disfiguring past. If the 2007 budget was the moment of triumph for the Mbeki's government and its prudent management of the economy, the fiscal crisis of 2008 was the start of its denouement.

In February 2008, the same finance minister was warning Parliament that "there are storm clouds ahead". The economy contracted throughout that year and by May the following year was in full recession. Growth recovered in November 2009, but since then has remained fragile. The recession coincided with the resignation of Thabo Mbeki as President in September 2008 following a bitter leadership contest within the ruling African National Congress which split the party. In April 2009 Jacob Zuma was elected President and the African National Congress returned to power in the national and provincial elections by a near two-thirds majority. The new President took office with the economy in decline, under enormous pressure to combat growing job losses, but with his party wounded and divided.

\section{Rapid economic crash, slow recovery}

In 1996 the national government introduced a macro-economic policy framework, the Growth, Employment and Redistribution Strategy (known as GEAR), that sought to achieve an economic growth rate of 6 per cent through 2000 (subsequently changed to 2014). Government believed that faster and sustained growth was essential to overcome the unsustainable levels of unemployment and poverty in the country. ${ }^{6}$ Government's strategies to achieve those objectives included stimulating export-led growth through industrial incentives and by maintaining a competitive exchange rate policy, containing inflation within 'competitive levels' (a 3-6 per cent of GDP band), aggressively reducing the deficit, reprioritizing public expenditure on capital investment and meeting basic needs, privatizing state assets, and investing in skills development.

The economy had grown steadily since 1999, with real growth averaging 5 per cent between 2003 and 2007, and by 2007 was approaching the desired 6 per cent level needed to halve poverty and unemployment by 2014 in line with government's policy goals. ${ }^{7}$ Per capita GDP had also grown by 22 per cent since

\footnotetext{
5. Manuel, Trevor, 2008, "Budget Speech: Address by the Minister of Finance to Parliament", 20 February, 1. 6. Republic of South Africa, 1996: Growth, Employment and Redistribution (GEAR): A Macro-economic Strategy, Pretoria, 2-3.

7. Manuel. Trevor, 2007a, "Medium Term Budget Policy Statement: Address by the Minister of Finance to Parliament”, 30 October, Cape Town, 2.
} 
1999, fixed capital investment by 10 per cent since 2002, and more than 1.5 million jobs had been added to the economy in the past five years. ${ }^{8}$

By 2008, government was forecasting a contraction of the economy that year and only moderate growth over the medium term "as the global economy begins to recover." "The upbeat tone of a year earlier had changed to one of reassuring the public that the country was well prepared to weather the coming storm. ${ }^{10}$

Sharp declines in GDP of 7.4 per cent and 2.8 per cent followed in the first two quarters of 2009, putting the economy into recession for the first time in 17 years. ${ }^{11}$ Overall, there was a 1.8 per cent GDP contraction in $2009 .{ }^{12}$ According to a recent survey of the South Africa economy "the change in the growth rate of real GDP between 2008 and 2009 represented the largest single-year slowdown on record for South Africa, and was larger than in most advanced and emerging economies, though far from being the worst." 13

The main causes of the recession were related to trade and financial flows and a sharp reduction in consumer demand and private investment in the economy. ${ }^{14}$ South Africa is a middle income country whose economy is reliant on financial services and the export of manufactured goods and primary commodities (such as gold, platinum and chrome). ${ }^{15}$ Portfolio inflows also accounted for the bulk of the financing of the country's large current account deficits in the years leading up to the crisis. ${ }^{16}$ The effect of the global financial crisis was that commercial credit and consumer demand evaporated, export and import volumes plummeted and net financial inflows turned to net outflows, resulting in a sharp decline in share prices. ${ }^{17}$ The manufacturing sector's value add declined by 12.2 per cent in the first 9 months of 2009 due to sharp year on year declines in the output of the automotive industry ( 34 per cent), the furniture industry (20 per cent) and

8. See Manuel, 2007: 2-3, op. cit; Manuel, 2008: 3, op. cit. In 2007. Manuel was expecting growth to reach 4.5 per cent in 2008 "before returning to about 5 per cent in 2009 and 2010."

9. Manuel, Trevor, 2008: "Medium Term Budget Policy Statement: Address by the Minister of Finance to Parliament”, 21 October, Cape Town, 4.

10. Manuel, Trevor, 2008, op. cit., 2.

11. International Labour Organization (ILO), 2010: "South Africa's response to the crisis", in: G20 Briefs, April, 1.

12. National Treasury, 2010: Budget Review 2010, 27 February, Pretoria, 13.

13. Organization for Economic Cooperation and Development (OECD), 2010: "Economic Surveys: South Africa”, July, 22.

14. OECD, 2010, op. cit., 22.

15. The composition of GDP in 2009 by major sector were finance, real estate and business services (21.5 per cent); manufacturing (14.8 per cent); general government services (13.6 per cent); and trade and accommodation (12 per cent). Mining only contributed 5.2 per cent of GDP. The source of this data is National Treasury, 2010, op. cit., 28.

16. OECD, 2010, op. cit., 22.

17. OECD, 2010, op. cit., 22; see also the South African government's own assessment in National Treasury, 2010: 29, op cit. 
the textiles and clothing sector (14.6 per cent). ${ }^{18}$ These declines in turn affected export volumes and thus the trade deficit.

Growth recovered in late 2009, rising to 3.2 per cent in the fourth quarter due to "a recovery in the global economy, higher commodity prices and sustained growth in government spending." ${ }^{19}$ Despite the massive fall in GDP in 2009, the recession was much 'shallower' than elsewhere because the country did not experience any major bank or firm failures, and the decline was offset by lower oil prices and strong growth in the construction industry (value add grew by 8.4 per cent in 2009) in preparation for the FIFA Soccer World Cup. ${ }^{20}$ The banking sector in South Africa was more resilient than in many other countries due to "banks" strong profitability, low level of non-performing loans, comfortable capital cushions going into the downturn, and a lack of direct exposure to problem assets in the US and Europe." 21

The economy was expected to grow at 2.3 per cent in 2010, largely due to the returns on investments in the World Cup and massive public sector investment in economic infrastructure, increasing to 3.6 per cent by 2012. These levels approximate levels of growth in 1996 when government introduced GEAR and are well below the 6 per cent needed to reduce poverty and unemployment by half.

\section{A 'jobs bloodbath'}

The rate of unemployment in the country has remained at chronic or nearchronic levels since 1994. Reducing the high level of unemployment by stimulating job creation in the formal economy has been a cornerstone of public policy in all four governments since democracy. Indeed government had justified introducing the controversial macro-economic austerity strategy GEAR in 1996 on the grounds that it would lead to the 6 per cent growth rate that was needed to reduce unemployment by half by 2014 . Achieving faster growth and job creation was also behind the Mbeki government's Accelerated and Shared Growth Strategy which was introduced in 2006 to remove constraints to economic growth.

Although unemployment has never fallen below 20 per cent, by early 2008 it had fallen to 21.9 per cent, before rising 2.4 points to 24.3 per cent in $2009 .{ }^{22}$ With the loss of 171,000 jobs, the unemployment rate had risen to 25.2 per cent by the first quarter of $2010 .{ }^{23} \mathrm{New}$ job creation also halved over the period as

18. National Treasury, 2010: 29, op. cit.

19. ILO, 2010, op.cit.1; the quote comes from National Treasury, 2010: 13, op. cit.

20. OECD, 2010, op. cit., 25.

21. OECD, 2010, op. cit., 26.

22. ILO, 2010, op. cit., 1.

23. Isa, Miriam. 2010, "Shock as jobless toll increases" to 25.2\%, in: Business Day, 5 May, 1. South Africa uses two measures of unemployment. The official measure does not include unemployed people who were not look- 
output and new investment contracted. The effects of higher unemployment and lower job creation were not borne by all sectors of the economy equally. The majority of the job losses were in the more labour intensive sectors of the economy (manufacturing, construction, trade and mining sectors), and hence the semiskilled, unskilled and the youth sectors of the work force bore the brunt of the recession: Of the 870,000 jobs lost in 2009, 527,000 were in the unskilled and semi-skilled categories, and youth unemployment (the 15-24 age group) declined by 13.6 per cent $(219,000)$ with 48.3 per cent out of work. ${ }^{24}$ These sectors were disproportionately affected by the recession due to structural changes and distortions in the economy: a shift from primary to tertiary sectors and exports, a low skills base, and declining demand for unskilled labour.

The consequence of such high job losses have been felt by the most vulnerable - children. The global crisis aggravated the decline in child poverty and hunger, with the severest impact among the very poorest children. ${ }^{25}$

\section{The impact on national government}

Given the dramatic and rapid economic downturn, the national government felt the impact acutely; as its revenue contracted, the social demands on its services increased. In large measure, the national government absorbed the full impact of the global financial crisis and the fallout from the 2008/2009 recession. The explanation is to be found in the structure of South Africa's federal system. First, the national government is exclusively responsible for all aspects of economic and fiscal policy in the state. It controls all of the major tax instruments (personal income, companies, and value-added taxes) and is responsible for collecting revenue and dividing it between the three orders of government. It also establishes monetary policy for the country, which is administered by the South Africa Reserve Bank through inflation and currency controls.

Second, the revenue raising powers of the provincial and local orders are both limited and subject to national regulation, and thus both orders present little or no fiscal risk to the national economy. Third, the primary function of the provincial and local orders is to provide infrastructure and social services to meet national policy goals for growth and poverty reduction. Hence both orders are in varying degrees dependent on national transfers to fund their running costs. Fourth, the highly centralized federal system coupled with a party list electoral

\footnotetext{
ing for employment in the past six months. The expanded measure includes these discouraged work-seekers. Unemployment is much higher on the expanded measure, standing at 31.2 per cent in April 2010.

24. National Treasury, 2010: 39, op. cit.

25. Financial and Fiscal Commission, 2010, "Submission For the Division of Revenue Bill 2010/11", RP71/2010, May, Cape Town, 26.
} 
system and the dominance of a single party at all levels of government means that national politics and policy priorities dominate political affairs in the country.

The global financial crisis had a direct impact on the national government. First and foremost, public expenditure as a percentage of GDP has exceeded revenue, with the deficit funded through substantially increased borrowing. The declining revenue growth, which has slowed budget growth, forced expenditure re-prioritization. However, social assistance has grown sharply in response to rising unemployment and higher consumer inflation. Furthermore, public employment grew strongly as a percentage of GDP, exceeding private sector employment. Finally, the economic crisis has resulted in social and political fallout, in the forms of rising social instability and growing tensions over macro-economic policy in the ruling alliance (comprising the ANC, the South African Communist Party and the trade union COSATU).

\section{Declining revenue, growth in public debt}

The global financial crisis effectively re-shaped the country's fiscal framework because the budget went from a surplus of 1 per cent of GDP in 2007/08 to a deficit of 7.3 per cent in just two years. ${ }^{26}$ Although the 2010 budget did not envisage either major cuts in public expenditure or significant changes to tax policy, government revised its fiscal stance to increase the public debt in order to fund increased expenditure and offset the projected fall in revenue. ${ }^{27}$ As a consequence, public debt was projected to rise from 23 per cent of GDP in 2008/09 to about 40 per cent in $2013 .^{28}$ These increases were not a direct response to the crisis but rather reflected a counter-cyclical response focused on stimulating growth through increased public investment. ${ }^{29}$

\section{Increased social assistance}

Stalled job creation, rising levels of unemployment and higher consumer inflation due to the recession have also led to an increase in public expenditure on the social wage as more people move from formal employment to dependence on state-provided relief. Levels of poverty had declined from 50 per cent to

26. Gordhan, Pravin, 2010, "Budget Speech: Address by the Minister of Finance to Parliament", 17 February, Cape Town, 12.

27. The revised estimates for 20082009 showed that expenditure $(28.2$ per cent) now exceeded revenue (23.3 per cent) as a percentage of GDP. The shortfall would be financed through increased borrowing. National Treasury, 2010: 61. op cit. A budget deficit of 7.3 per cent was projected for 2009/10, falling to a projected 6.2 per cent the following financial year, before reducing further to 4.1 per cent by $2012 / 2013$. National Treasury, 2010: 13, op. cit.

28. Gordhan, Pravin, 2010, op. cit.

29. OECD, 2010, op. cit., 29. 
21 per cent between 2000 and $2008 .^{30}$ The fall in poverty was largely attributable to growing levels of direct income support to poor households in the form of social security grants. ${ }^{31}$ Social assistance in 2009 was 3.5 per cent of GDP with about 14 million people dependent on direct income support, with growth in assistance averaging 12 per cent between 2006 and 2009. ${ }^{32}$ During the period of the recession new claimants to the government controlled unemployment insurance fund increased by 42 per cent and the amount of benefits paid out by 57 per cent. ${ }^{33}$ Massive unemployment coupled with a high and growing social wage has led to a dangerous distortion in the labour market: South Africa now has more people who are grant recipients (13.8 million) than working taxpayers (12.8 million). ${ }^{34}$

\section{Social and political fallout from the financial crisis and recession}

Aside from the recession's direct impact on employment and livelihoods, the social and political costs of massive unemployment particularly amongst the youth are incalculable. The risks of crime and social instability are greatly increased when 75 per cent of the unemployed population are below the age of 35 . Since 1996 South Africa has experienced a spate of violent service delivery protests, mainly in the informal settlements surrounding major cities. In 2008/2009 the number of protests was the highest on record, suggesting that the economic impacts of the downturn are also fuelling public discontent and instability. Persistent and extremely high levels of unemployment and income inequality have also added to the tension within the ruling party alliance over macro-economic policy. On the right, the ANC's powerful youth wing supported by a group of nationalists is calling for the nationalization of the country's mines. On the left, the powerful labour unions are calling for changes to macro-economic policy, including increased deficit spending and the devaluation of the rand to stimulate the value of exports. The rate of job losses, the disparate impact on the working class, and the wide disparity between the pay of management and workers has drawn fierce criticism from the labour unions and fuelled the recent industrial action in the public sector of salary increases. ${ }^{35}$ At the time of writing, the public

30. National Treasury, 2010: 116, op. cit. National Treasury's calculation is based on people living below the line of R367 per month (2007 constant rands). Presidency of the Republic of South Africa, 2008. Development Indicators 2008, Pretoria, 26.

31. The three major non-contributory social assistance grants are the child support grant, disability grant and old age grant (See National Treasury, 2010, op. cit., 105).

32. National Treasury, 2010, op. cit., 104.

33. National Treasury, 201, op. cit., 107.

34. Hazelhurst, Ethel, 2010, "Ticking tax time bomb as too few at work", in: Cape Times Business Report, 2 July, 15.

35. For COSATU's assessment of the dire impact of the recession on workers see COSATU, 2009a. "Address by the Secretary-General Zwelinzima Vavi to the South African Communist Party Congress", 11 December; 
sector is engaged in a country-wide strike over demands for an 8.6 per cent salary increase. This demand by the public sector unions would exceed budgeted salary expenditure by 3.7 billion rand.$^{36}$ Moreover, the strike represents a direct challenge to the Minister of Finance's claim in his 2010 budget speech that the country could not afford a further major increase in the public salary bill. The Secretary-General of COSATU has explicitly confirmed that the strike is a political response to the hardship that workers are suffering as a result of the recession and conservative economic policy: "Of course the strike is political. It is workers making political statements." ${ }^{37}$

\section{The impact on provincial government}

Provinces are largely concerned with the implementation of national policies in the fields of education, health and social welfare. In the latter field, the distribution of income support grants (pensions, disability and child support grants) was 'nationalised' from the provinces with the establishment of the South African Social Security Agency (SASSA), a national organ of state, assuming responsibility for the distribution of the grants. With negligible own revenue, their functioning is dependent on national transfers, in the form of unconditional or conditional grants. In 2008/09 the provinces received 42.7 per cent of national raised revenue. ${ }^{38}$ This amount comprised 96.3 per cent of total provincial revenue, with 3.7 per cent derived from own receipts. ${ }^{39}$ Three quarters of all provincial expenditure went to social services (concurrent functions with national government), with the lion's share going to school education ( 40.8 per cent) and primary health care $\left(28.5\right.$ per cent).$^{40}$ As provincial expenditure gives effect to major national priorities in the new government's policy agenda, the national government's fiscal stance has cushioned provinces from the worst effects of the crisis (by protecting expenditure commitments on social services), but could not insulate provinces entirely.

COSATU, 2009b, "Address by the Secretary-General Zwelinzima Vavi to the National Congress of the National Union of Mineworkers", 28 May; COSATU, 2009c, "Is the pay gap between executives and workers justifiable?" Paper presented by Patrick Craven, COSATU National Spokesperson's to the SARA Conference, 30 October; and COSATU, 2009d: "Address by the Secretary-General Zwelinzima Vavi to the National Congress of the SAMWU”, 3 November.

36. Enslin-Payne, Samantha, 2010, "Public sector out on strike for $8.6 \%$ hike", in: Cape Times Business Report, 10 August, 14.

37. Letsoalo, Matuma, 2010, “COSATU strikes out at high office”, in: Mail and Guardian, August 20-26, 11. According to Letsoalo "the strike is seen as a strategy by COSATU to put the ANC government under pressure to review its economic policies."

38. National Treasury, 2009: "Provincial Budgets and Expenditure Review 2005/06-2011/12”, September, Pretoria, 2 .

39. National Treasury, 2009, op. cit., 7.

40. National Treasury, 2009, op. cit., 13. 
First, the job losses added to already high provincial unemployment rates and exacerbated existing regional economic disparities. In the fourth quarter 2009, the unemployment rates in 7 of the 9 provinces exceeded the national rate of 24.3 per cent. The unemployment rate was the highest in South Africa's poorest and most impoverished province, the Eastern Cape, followed by other provinces with large rural populations. ${ }^{41}$ Even as the recovery began, only two provinces posted job growth in the first quarter of 2010, the Western Cape and Kwa-Zulu Natal, and most showed continuing job losses. ${ }^{42}$ In short, the already impoverished provinces became even poorer. The economic recession thus increased the pressure on social assistance expenditure in provinces. ${ }^{43}$

Second, declining national revenue will see reduced provincial budget growth over the medium term. National government's fiscal stance was to maintain levels of social expenditure despite declining revenues while effecting savings through expenditure re-prioritization over the medium term. The 2010 budget provided increased allocations to provinces above the baseline. The effects of the recession and the reduction in revenue are, however, visible in the sharp decline in the growth rate of provincial budgets. The National Treasury projects that the annual average growth rate in provincial expenditure will have halved from 17.5 per cent in 2006/07-2009/10 to 6.9 per cent in 2009/10-2012/13 ${ }^{44}$ Provincial revenue growth will fall from 17.2 per cent to 7.6 per cent over the same period.

With only moderate economic growth projected over the next three, mounting pressure on social services due to increased unemployment, declining provincial budget growth could prove to be a factor in the country not meeting Millennium Development Goal targets in the areas of health and education, the two main provincial responsibilities.

Third, despite declining national revenue, increased public salaries and employment have occurred that has led to above inflation growth in the provincial salary bill. ${ }^{45}$ Provinces employ over 850,000 of the country's 1.2 million public servants, with the majority employed in the education (40 per cent) and health

41. According to the National Treasury Statistics South Africa's Labour Force Survey for the first quarter of 2010 showed that "only 29 per cent of working age adults in Limpopo and 31 per cent in the Eastern cape have jobs." National Treasury, 2010: 42, op. cit.

42. Statistics South Africa, 2010, “Quarterly Labour Force Survey, first quarter 2010, Statistical Release P0211”, May, vii.

43. From $2006 / 7$ to $2009 / 10$, social assistance expenditure grew from R57 billion to R80 billion, with the highest expenditure in the three poorest provinces (KZN: R19 billion, Eastern Cape: 14 billion, Limpopo: R10 billion). The projected 11 per cent growth in expenditure projected through this period to 2012/13 is an indication of rising pressure on direct income support as a result of deepening poverty in part due to the recession.

44. National Treasury, 2010, op. cit., 138.

45. The 2009 salary negotiations coincided with the economic recession and resulted in above inflation salary increases of between 6 and 10 percent, with compensation increasing by about R2 6 billion (National Treasury, 2010, op. cit., 120. The public service wage bill has almost doubled in the past five years (Gordhan, 2010,op. cit., 20, with the provincial bill alone accounting for about R64 billion. 
(20 per cent) sectors. ${ }^{46}$ Both are priority sectors for government and crucial to long term poverty reduction and development. Salary levels for the public service (which comprises both the national and provincial spheres) are determined through negotiations between the national government and labour in a national collective bargaining process. The provincial compensation budget is then adjusted through the division of revenue process to accommodate salary increases. Provincial social services are labour intensive and therefore salaries average about 55 per cent of total provincial expenditure. ${ }^{47}$

What factors prompted the expansion of the salary bill? Part of the answer lies in the second element of the perfect storm, the disintegration of a strong political and policy centre. After the departure of Mbeki, and with him the certainty of his economic policy, a weak and vacillating national executive was buffeted by demands of the trade unions (who contributed much to Zuma's ascendency) and a view of the state as the employment agency of the new political elite. Wage negotiations were thus not tempered in the face of fiscal shortages. All that the new Minister of Finance, Pravin Gordhan could do is complain in his 2010 budget speech that the massive salary increase "has placed immense pressure on the budget." 48

\section{The impact on local government}

The recession has compounded the fragility and instability of local government. Those municipalities whose local economies relied on foreign trade, petrol, steel and motor manufacturing felt the pinch first. ${ }^{49}$ The impact was, however, widespread and the sharp edge of the recession immediately became visible at local level by the spike in violent service delivery protests.

The country's 283 municipalities provide basic services such as water, electricity and sanitation that are essential to sustain human well-being and economic development. As a result of apartheid, there were massive backlogs in infrastructure and services in townships and rural areas. Consequently, municipal services are heavily subsidized by the state both to address the backlogs and to combat poverty by providing the poor with a basic level of free water and electricity. Since 1994, municipalities have made enormous strides in extending infrastructure and services to poor communities. But the municipal system is also beset with several problems: Corruption and rent-seeking are widespread, if not endemic to local government. The technical and managerial skills base is thin. Assets are wasting

46. National Treasury, 2010, op. cit., 120.

47. National Treasury, 2010, op. cit., 18.

48. Gordhan, Pravin, 2010, op. cit., 20.

49. Savage, David, 2009, “Coping with crunch time: What the recession means for local government", in: Local Government Bulletin 11(3), 10. 
as a result of poor maintenance. And funding is inadequate for local government to meet its constitutional mandate of providing basic municipal services. It is estimated that addressing the existing infrastructure backlogs by 2014 will cost almost the entire country's annual budget. ${ }^{50}$ They are also symptoms of a growing chasm between the public's expectations of local government and local government's capacity to meet those expectations. The clear signs of growing public frustration with local government are in the form of violent public protests over municipal corruption and service delivery failures that have become daily fixtures throughout the country.

Overall, about 26 per cent of municipal revenue comes from national transfers in the form of unconditional and conditional grants. ${ }^{51}$ This average conceals huge variations in the transfers; the six metros whose total budgets constitute 67 per cent of all municipal budgets, receive 27 per cent of their operating income from transfers, while for rural municipalities the figure can be as much as 90 per cent. While there has not been a cutback in transfers, the growth of local government share in the national revenue since the recession is down to 8.4 per cent for the period $2009 / 10$ to $2012 / 13$, significantly below the 21.3 per cent annual average growth between $1995 / 96$ and 2007/08..$^{2}$

Although there were no cuts in local government's budget we argue that the financial crisis has had a much more visceral and direct impact on local government than on the other two orders. First, municipalities have had to absorb the high increases in the cost of bulk electricity supply. Coinciding with the recession was a significant increase in electricity prices, the antecedents of which predates the crisis. ${ }^{53}$ Not only did this lead to a reduction in electricity consumption by business, but many households could not pay their accounts, leading in both instances to a reduction in municipal income. ${ }^{54}$

The two main sources of local revenue are services charges for electricity and water and property rates. The financial crisis has impacted on these revenue

50. These problems are well documented in national government's recent assessment of the state of local government in the country. Department of Cooperative Governance and Traditional Affairs (CGTA), 2010, "National report on the state of local government", Pretoria.

51. National Treasury, 2008, "Local Government Budgets and Expenditure Review 2003/04-2009/10", Pretoria, 23.

52. National Treasury, 2010, op. cit., 139.

53. In 2010 the National Energy Regulator of South Africa (NERSA) approved that the state's electricity supplier ESKOM's increase the price of electricity by 24.8 per cent, 25.8 per cent and 25.9 per cent over the next three years. National Electricity Regulator of South Africa (NERSA), 2010. NERSA's decision on ESKOM's required revenue application - multi-year price determination 2010/11 to 2012/13 (MYPD2), press release, 25 February. The price hikes have translated into higher municipal electricity tariffs.

54. In the case of Johannesburg, it is reported that from an average collection rate of $75 \%$ of operating revenue, it dropped to $61.8 \%$ in 2009. Everatt, David, Graeme Gotz, Sizwe Phakathi and Neva Makgetla, 2009: Benchmarking the way cities and regions around the world are responding to the global recession, Report for the Gauteng Provincial Department of Economic Development, Gauteng City-Region Observatory, 21. 
sources in two direct ways. The decline in household income due to increased unemployment and rising inflation has resulted in increased levels of non payment for municipal services. Although outstanding consumer debt has always been high, as at 31 March 2010, R56 billion was owed to municipalities, a year on year increase of R219 million. Although the figures are not yet out, it is likely that the slowdown in the property market and new investment in the built economy as a result of the recession will see a decline in income from property rates. The result has been that municipalities increasingly face cash flow problems as their income declines but their expenditures proceed. ${ }^{55}$

As the government closest to the people, municipalities were also the most vulnerable when the citizens turn their anger towards the state. Between January and August 2009 there were 52 major protests, almost double the number of protests for the whole of $2008 .^{56}$ About 30 per cent of these were in the highly urbanized Gauteng, which has experienced major job losses, which suggests some correlation between increasing levels of protest and rising urban unemployment and hardship..$^{57}$

\section{THE STATE'S RESPONSE TO THE FINANCIAL CRISIS}

In this section we examine the package of measures that the three spheres of government introduced to ameliorate the effects of the financial crisis while stimulating long term growth.

\section{National government's response}

During the financial crisis, national government and in particular the outgoing and incoming ministers of finance (Trevor Manuel until April 2009 and thereafter Pravin Gordhan) played a decisive leadership role in preparing the public for the storm and leading the way to economic recovery. Four messages were consistently communicated: First, government's prudent management of the economy and public finances had put the country in a strong position to weather the worst effects of the financial crisis provided the country stood together. ${ }^{58}$ Second, government had taken appropriate steps to soften the blow on the poor and did not intend to cut public spending on essential social services. Third, increased public investment in economic infrastructure would stimulate future

55. Savage, David, 2009, op. cit., 9.

56. CGTA, 2010, op. cit., 11.

57. CGTA, 2010, op. cit., 10.

58. Manuel, Trevor, 2009, "Budget Speech: Address by the Minister of Finance to Parliament", Cape Town, 11 February, 25; and Gordhan, Pravin, 2009b, "Medium Term Budget Policy Statement: Address by the Minister of Finance to Parliament", Cape Town, 27 October, 5. 
growth. ${ }^{59}$ Fourth, as growth re-merged, the need to define a new growth path for the country became the dominant line. ${ }^{60}$ This section examines the key elements of the national response.

\section{An integrated response to economic downturn}

With the country facing its first recession in 17 years, the February 2009 budget represented "a budget in time of crisis." principles that would guide public spending through the crisis. These were "protecting the poor, creating employment, investing in infrastructure, promoting competitiveness, and fiscal sustainability." ${ }^{62}$ These sentiments were also echoed by a presidentially convened joint economic work group comprising business, organized labour; community organizations, and the national government to develop South Africa's response to the crisis. ${ }^{63}$ The task force reached an agreement and issued on 19 February 2009 a document called Framework for South Africa's response to the international economic crisis.

The framework called for "social solidarity between all South Africans to ensure that the crisis does not damage the fabric of society" and "collective responsibility to work together to withstand the crisis and to ensure that the poor and the most vulnerable are protected as far as possible from its impact." "64 For the most part the document restated the principles already announced in the budget. Its importance lay in the fact that it reflected a clear consensus amongst the social partners on the need for 'bold action' in facing the crisis, and more importantly on specific 'stimulus measures' to combat the worst effects of the crisis on employment and the poor. ${ }^{65}$ This not only strengthened the national government's hand in leading the country's response but constituted a national consensus about the nature of that response and the part that each sector would have to play. Remarkable, if not unsurprising, was the fact that provinces and local government, which would both have important implementation roles to play, did not participate in the process of developing a national response.

59. Gordhan, Pravin, 2010, op. cit., 7.

60. Gordhan, Pravin, 2010, op. cit., 7.

61. Manuel, Trevor, 2009, op. cit., 7.

62. Manuel, Trevor, 2009, op. cit., 8.

63. Manuel, Trevor 2009, op. cit., 8.

64. Presidential Joint Economic Working Group (PJEWG), 2009: Framework for South Africa's response to the international economic crisis, 19 February, 3.

65. PJEWG, 2009, op. cit., 5. 


\section{Stimulating employment growth through infrastructure investment}

The main thrust of the state's response to the crisis was the public sector's $\mathrm{R}$ 846 billion investment in infrastructure in order to stimulate growth and employment through to $2013 / 14$. This was not a crisis-driven stimulus so much as a planned investment to improve the productive and employment capacity of the economy that fortuitously coincided with the downturn. State-owned entities are responsible for most of the spend, which goes to building new power stations, public transport infrastructure and upgrading bulk water supply infrastructure. ${ }^{66}$ Overall stimulus investment also included the R33 billion spent on the stadiums and other infrastructure that were necessary to prepare the country to host the 2010 FIFA Soccer World Cup. ${ }^{67}$ Although not the bulk, a significant portion of the infrastructure spending would be effected by provinces and municipalities, in particular, through the Municipal Infrastructure Grant (MIG).

\section{Increasing short term work opportunities in public works}

Expanding the public works programme to boost short term employment and skills development, for women and youth especially, was a key intervention under the social partnership framework that aimed to draw in 4.5 million beneficiaries between 2009 and $2014 .{ }^{68}$ In 2009 government announced it would create half a million work opportunities through this programme by the end of that year, and reportedly achieved 97 per cent of that target. ${ }^{69}$ These are temporary work assignments with a skills development component, not formal jobs in the main economy. The 2010 budget added R52 billion to public works employment, with about 2.5 billion going to 'labour-intensive' projects aimed at rural development. Again, provinces and municipalities would be significant implementers of the expanded public works programme through, for example, their own road construction and maintenance programmes.

\section{Maintaining levels of social expenditure and effecting savings through reprioritiza- tion}

Maintaining existing expenditure was essential to protect the poor, stimulate long term growth, and give effect to the new government's policy priorities. But

66. Gordhan, Pravin, 2010, op. cit. 20; Gordhan, Pravin, 2010a, "South Africa’s Infrastructure and legacy after the 2010 FIFA World Cup and what it means for an emerging economy", Speech by the Minister of Finance delivered to the Financial Times Future and Legacy Dinner hosted by the International Marketing Council, 22 July, 5.

67. Gordhan, Pravin, 2010a, op. cit., 3 .

68. PJEWG, 2009, op. cit., 15.

69. Zuma, Jacob, 2010, "State of the Nation address by the President to Parliament", 11 February, South African Government Information, www.info.gov.za/speeches/2010/10021119051001.htm 
the combination of locked in expenditure commitments and revenue contraction restricted budget growth to a low 2 per cent in real public spending for the year. ${ }^{70}$ Savings of 25 billion were extracted from departmental budgets by cutting non essential expenditures and reprioritizing resources to more important priorities linked to the government's policy programme. ${ }^{71}$ Yet, as will be shown below, cuts in service are occurring at both provincial and local level.

\section{Increasing deficit spending and public borrowing to fund expenditure}

Systematically reducing the budget deficit as a percentage of GDP had been a cornerstone of macro-economic policy since 1996. Over the years criticism of fiscal austerity had mounted within the labour movement and spurred on by the job losses the attacks intensified during the recession. COSATU blamed the crisis on "conservative monetary and fiscal policy." 72 The fear on the part of the business community was the opposite, namely that under the influence of its left-wing the new government would change policy direction on the economy. There was considerable uncertainty in the country in the months ahead of the government's first budget. Although the 2010 budget affirmed the foundations of the existing macro-economic policy it conceded the need to run a deficit, financed from a larger debt book, "given the need for rapid economic growth to boost employment."73 At the same time it would balance that eventuality with the demands of long term fiscal sustainability because the country "could not afford too sharp a rise in debt." "74 The outcome of this balancing act is that debt rises from 22.7 per cent of GDP in 2008/09 to 44 per cent in 2015/16 before stabilizing. ${ }^{75}$

\section{Introducing a wage subsidy for the youth}

High youth unemployment put the need to ensure faster youth employment at the centre of government's response to the recession. To help "put young people to work" government will offer a tax rebate to employers to "lower the cost of hiring young people without experience." ${ }^{76}$ Government estimates that about 800,000 people will qualify but the aim is to raise employment of young school-leavers by a further 500,000 by $2013 .{ }^{77}$ As a tax concession, the programme is implemented at the national level.

70. Gordhan, Pravin, 2010, op. cit., 17.

71. National Treasury, 2010, op. cit., 117.

72. COSATU, 2009a, op. cit., 2.

73. National Treasury, 2010, op. cit., 8.

74. National Treasury, 2010, op. cit., 8.

75. National Treasury, 2010, op. cit., 8.

76. Gordhan, Pravin, 2010, op. cit., 10.

77. Gordhan, Pravin, 2010, op. cit., 10. 


\section{Moderate cuts in the interest rate}

The compact between the social partners signed in February 2009 affirmed the role of the South African Reserve Bank in monetary policy. ${ }^{78}$ The bank's policy on inflation during the recession, providing only modest interest rate cuts, had drawn criticism from the unions. COSATU claimed that the Bank's decision to keep interest rates unchanged when other countries were cutting theirs dramatically showed that it "didn't care a damn what happens to the economy, job creation" ${ }^{79}$

\section{Defining a new growth path for the country}

The blunt comments by COSATU foreshadowed larger arguments about defining a new growth path of the country. The national government saw the crisis as an opportunity to define a new growth path for the country. ${ }^{80}$ But recalibrating the country's expectations and forging a new national consensus on economic growth and job creation were also political necessities. The recession had shattered the country's goal of halving poverty and unemployment by 2014. The mounting job losses had also begun to strain the creaky alliance between the ruling party and its labour union that had shown Mbeki the door. The extent of the job losses thus increased the pressure on government to justify to its own, increasingly disgruntled constituency, why it continued to retain a conservative economic policy stance.

With concessions to labour and business alike, the 2010 budget speech proclaimed that there was "substantial agreement that our key challenges are job creation, poverty reduction and faster economic growth." 81

Provinces and local government would be key implementers in the strategy. As major employers, provinces and local government would contribute significantly to the public employment opportunities to the youth and well as the expanded public works programme. Local government in particular would be involved in public investment, and provinces would principally be responsible for ensuring quality school education.

\footnotetext{
78. PJEWG, 2009: 8, op. cit.

79. Mail and Guardian online, 25 June 2009, at http://www.mg.co.za/article/2009-06-25-cosatu-reserve-bankdoesnt-care-a-damn, viewed 6 August 2010. Interest rates were cut by only 500 basis points during the recession, which was "not aggressive by international standards." OECD, 2010, op. cit., 29.

80. Gordhan, Pravin, 2010: 6, op. cit.; Gordhan, Pravin, 2009, op. cit., 15.

81. Gordhan, Pravin, 2010, op. cit., 6.
} 


\section{Provincial government's response}

The structure of the state and the country's economy provided little room for provinces to map out a response to the crisis that was significantly different to national government's lead. Provinces have no constitutionally entrenched taxing powers and those powers authorized by national legislation are insignificant. Provincial governments are not allowed to run a deficit budget on their operating accounts; they must provide balanced budget and are constitutionally not permitted to borrow for operating expenditure. They could thus not devise fiscal stimulus expenditure packages of their own. ${ }^{82}$ Even politically, the national government's commitment to protecting social expenditure budgets was its own initiative; it was not induced into taking that stance by any pressure which provinces were exerting. Indeed the nature of concurrent responsibilities means that national and provincial policy interests are virtually indistinguishable. Because provinces actually provide the services to meet national policy goals, national government had every incentive to protect provincial budgets. The new consensus on the country's response to the crisis that had been forged amongst the social partners therefore also reflected, if not an intergovernmental consensus between the national and provincial orders, then at least an acceptance by provinces of national government's lead and conformity with the line taken by the social partners.

The intergovernmental conformity also cut across party lines. There was one important change in the provincial landscape after the 2009 provincial elections. An opposition party, the Democratic Alliance, had wrested control of one province, the Western Cape, from the African National Congress. The 2010 provincial budget policy statement for that province, however, reveals little dissonance between the provincial government's political objectives and national goals. ${ }^{83}$ Sounding the same line as the national finance minister, the provincial government acknowledged that "reduced fiscal space will necessitate the reprioritization of existing services in pursuit of finding savings to maintain and improve expenditure on key priorities" (such as health, education, and transport, which are all regulated by national policies). ${ }^{84}$ Hence, the provincial government's planned modernization programme for the province was about achieving greater efficiency in spending not effecting a substantively policy direction for the region. That was easier said than done. Currently, the provincial department of education is in the process of

82. Everatt, David et al, 2009: 47, op. cit.

83. Provincial Government Western Cape Provincial Treasury, 2009: Medium Term Budget Policy Statement, Cape Town, 1.

84. Provincial Government Western Cape Provincial Treasury, 2009: Medium Term Budget Policy Statement, Cape Town, 1. 
cutting 300 teaching posts as all other measures to reduce the education budget cut have not produced the necessary savings. ${ }^{85}$

Despite the limited room for a differentiated provincial response to the crisis, several provinces, particularly those that have experienced the worst job losses, have exercised some independent leadership and forged a provincial consensus on the appropriate response for their particular circumstances within the framework of the national response. The province of KwaZulu-Natal held a multi-stakeholder Economic Recovery and Jobs Summit in August in 2010 which reached consensus on the broad outlines of the province's trajectory for recovery and long term growth. ${ }^{86}$ The trajectory did not differ with the substance of the national framework. In 2010, Gauteng province, the country's economic hub, undertook a review of the province's economy, including the impact of the recession, and has established a provincial planning commission to plan long term economic growth and job creation. ${ }^{87}$ The province also commissioned a research report, entitled Benchmarking the way cities and regions around the world are responding to the global recession. ${ }^{88}$ The report contained a number of proposals, most of which related to soft policy measures, including the seeking of better cooperation with local and national government, and the need for filling vacant post in anticipation of the eventual upswing in the economy. The rise in the overall provincial salary bill suggests that the province has, whether or not by design, acted proactively on the latter recommendation.

\section{Local government's response}

Although facing the sharp edge of public anger, local government's scope for independent action was also limited, although not to the same extent as provinces. While deficit budgeting was not an option (municipalities must run a balanced budget and may not borrow for operating expenditure) responses could include raising tax revenue, reducing or deferring spending or improving spending efficiencies. ${ }^{89}$ Increased revenue raising was problematic; municipalities could not merely increase tariffs and rates to make up for their deficits, as that may result in higher levels of non-payment and increased bad debt. ${ }^{90}$ What remained was cutting back on services and achieving better efficiencies. These responses were not publicly communicated, although they may have been implemented in practice.

85. Fredericks, Ilse, 2010, "Schools fail to find ways to save posts", in: Cape Times, August, 17.

86. Mabuyakhulu, Mike, 2010, "Moving from bitter times to sweeter times: budget policy speech 2010/11 by KwaZulu-Natal MEC for Economic Development and Tourism to the KwaZulu-Natal Legislature”, April, 4-5. 87. Provincial Government Gauteng, "2010: Socio-Economic Outlook 2010”, Gauteng, 2 March, v.

88. Everatt, David et al, 2ww009: op. cit.

89. FFC, 2010, op. cit., 17.

90. Savage, David, 2009, op. cit., 11. 
Local government's articulated response was generally the same as the national response to recovery - the focus is on job creation and growth. In his state of the city address, the Mayor of Johannesburg, South Africa's largest municipality, recycled the same policy as the national government: the municipality must "contribute towards job creation, facilitate provision of decent employment opportunities and market-led integrated skills development programmes; create an investment-friendly environment to increase foreign direct investment; and facilitate economic growth underpinned by a vibrant small medium and micro enterprise sector." ${ }^{11}$ No practical measures to implement these goals were, however, forthcoming.

One important development over the period affecting local government directly was the national government's introduction of a turnaround strategy for local government in the country. The strategy was a direct response to ongoing public protests, widespread corruption and systemic service delivery failures in many municipalities. Because the strategy coincided with the recession and the new government taking office, it has inevitably translated national objectives for growth, efficiency and job creation into complementary outcomes and objectives for local government. These include improving financial management, effecting savings, and enhancing service delivery to meet basic needs. ${ }^{92}$

\section{CONCLUSION}

\section{What Are The Likely Long Term Effects Of The Global Crisis On South Africa's Politics And System Of Decentralised Government}

The national government in addressing the crisis is set to influence the functioning of an already highly centralised intergovernmental fiscal system. Indicators point, although not yet very dramatically, in the direction of greater centralisation.

First, it is evident that the national government and its social partners - principally the unions and business - set the tone on broad economic policy. Provinces and local government were not in any manner central to the negotiations of the deal, including a new national growth strategy. The national measures adopted affirmed their allocated role of being implementers of national policy, rather than co-authors thereof. They will play their part in job creation, infrastructure development and skilling the next generation's workforce.

The financial crisis again highlighted the limited room for provincial initiative. While the extreme case of vertical fiscal imbalance is well documented and lamented, when it came to responding to the crisis, provinces remained passen-

91. Masondo, Amos, 2009, "Masondo is upbeat about the future: State of the City address", 27 February, (http://www.sacities.net/2009/feb27_joburg.stm), accessed 12 August 2010.

92. National Treasury, 2010, op. cit., 129.

L'Europe en formation $n^{\circ} 358$ Hiver 2010 - Winter 2010 
gers in the national policy train. They had hardly any fiscal instruments with which they could have responded proactively to their financial woes.

Second, as provinces are the implementers of key national priorities and the 'national' resources to do so have contracted, there is likely to be a significant increase in the supervision of provinces. Should the national government become serious about combating graft and corruption, ${ }^{93}$ stricter monitoring rules will be implemented and limits on provincial discretion of using funds for matters other than national priorities, may follow. In this regard, the recent recommendations of the Financial and Fiscal Commission (FFC) are indicative of this trend.

The FFC, an independent advisory body established in terms of the Constitution, must annually advise the national government on the Division of Revenue Bill that distributes the revenue raised nationally between the three spheres of government and among the nine provinces. Its role is that of an independent adviser on matters affecting the intergovernmental fiscal system, advice that the national government must consider. In its short term recommendations on the 2011/2012 Division of Revenue Bill the FFC supported the national government's policy of spending on child support and old age pensions as effective anti-poverty interventions. It further urged the national government to maintain "high access levels to education and health services that it [the government] achieved even during the period of the global economic crisis." "The FFC's medium- to longterm recommendations suggest, however, a fundamental review of the financing model of education, health and the social wage. It recommended that the national government should -

1. Introduce a block grant for education, health and social development to fund clearly defined and costed outcomes in these areas.

2. Undertake independent cost effectiveness and quality review (across both public and private sectors) of education, health and the social wage. ${ }^{95}$

The FFC uses the term 'social wage' as referring to provinces' social services (which do not include any cash grants) and the free basic services (water, sanitation and electricity) which municipalities provide with their unconditional grant.

This recommendation of introducing a block grant for education, health and social development is a critique of the current system of providing provinces and municipalities with an unconditional grant - their equitable share of revenue

93. There are some indicators that at least in some Departments there is a conscious effort to tackle corruption through the institution of forensic investigations. The Department of Human Settlements has launched 20 investigations on 'dodgy' tenders (see Cape Times, 17 August 2010).

94. FFC, 2010, op. cit., 27.

95. FFC, 2010,, op. cit. 
raised nationally. At issue is whether provinces should have a constitutionally entrenched discretion to spend their equitable share according to their political preferences. For provinces the discretion reflects their meagre degree of autonomy. Although much of their discretionary spending on education, for example, is structured by nationally determined teachers' salaries, notionally the unconditional equitable share allows provinces to determine their own priorities. In contrast block grants are meant to ringfence transfers for specific spending priorities.

The second part of the recommendation is that the use of the ringfenced funds would further be circumscribed by "clearly defined and costed outcomes" in the designated areas. What the FFC in effect is saying is that the national government should clear define and cost education outcomes and that provinces will then be compelled to use the ringfenced funds to achieve those nationally determined outcomes. This renders provinces mere agents of the national government; they exercise minimal discretion, rendering provincial autonomy an empty shell.

The third part of the recommendation then follows logically: the national government should effect an independent review of how effectively and efficiently the provinces perform their agency function of achieving the clearly defined outcomes with the ringfenced funds. This means increased measures of monitoring.

The rationale of the FFC's recommendations is thus: access to education, health and the social wage is so important that provinces and municipalities cannot be trusted with an unconditional grant to give effect to these national priorities; their discretion should thus drastically be curbed. Implementing this recommendation would require, however, a constitutional amendment as it calls for a change in the discretionary nature of the equitable share. Should the National Treasury accept these recommendations, which it is wont to do, the role of provinces is then placed under further pressure: if they are merely acting as agents of the national government, why do they exist as political entities?

Third, will the crisis add fuel the debate on the future of the province? A conventional wisdom is that a "crisis is also an opportunity to put in place long-term changes - so don't waste a good crisis!' 96 Under the Mbeki government, a thorough review was done on the future of provinces, their role and, if they had any, whether it could be better executed by a reduced number of provinces. The policy review of provinces and local government, was neither enthusiastically endorsed nor rejected by the Zuma government. It provided, however, the space and the evidence to confront the long standing question about the future of provinces. The context of a national government facing a severe contraction of revenue and seeking to reprioritise expenditure, may spur the debate towards a 'cost saving exercise' of denuding provinces further of some functions, reducing their number or totally eliminating them. The first salvo has been fired. In the run up to the

96. Everatt, David et al, 2009, op. cit., 11. 
ANC's National General Council (NGC) at the end of September 2010 (the highest decision-making body between the five yearly National Conference), a discussion document reaffirmed that "the unitary state remains the ANC's philosophical orientation and point of departure." 97 Although the NGC would not make a final decision, it must "provide a policy framework and set of criteria for the possible reconfiguration of Provinces, be it the reduction in the number of Provinces or their being phased out." 98 Will such a framework emerge with a clear policy direction? The current turmoil in the governing party suggests not.

The replacement of Mbeki by Zuma did not resolve the ideological tiffs within the party. It merely allowed for more space for a variety of interests to contest and jockey for position. Economic debates rage between the Alliance partners - from African nationalists set on nationalising the mines, to the South African Communist Party and COSATU who seek a greater state control of the market. Amidst the contestation over economic policy and the ascendency of none, contesting the incumbency of provincial elites will be difficult. At the moment there is no coherent centre in the party that could take on entrenched provincial interests notwithstanding poor performance by provincial administrations and interminable intra-party factionalism in the regions.

Without a strong centre, decisive policy changes on provinces are not likely to feature at the forthcoming ANC NGC or at the next National Conference in 2012. A radical change to the status of provinces, riding on the back of the financial crisis is not likely, although not impossible depending on the balance of power at the time. More centralised levers of control over financial management in provinces and municipalities, such as suggested by the FFC, are, however, likely. Other costs saving measures have already been mooted. The alignment of the local government election cycle with that of the national and provincial elections is principally justified on the basis of cost savings, even though it may be at the expense of fostering local politics. ${ }^{99}$

Fourth, since the impact of the global economic crisis has had a disparate impact on provinces, exacerbating already existing differences, relations between provinces are likely to become strained. All provinces, but Gauteng and the Western Cape, are showing out-migration of population, placing additional financial burdens on the two receiving provinces. The Western Cape is complaining that it is providing services to residents of other provinces without the extra costs being reflected in the national transfers, as the equalisation formula is applied to

97. African National Congress (ANC), 2010, "NGC Discussion Document: Transformation of State and Governance”, para 37, http://www.anc.org.za/docs/discus/2010/legislaturez.pdf.

98. ANC, 2010, op. cit., 48.

99. ANC, 2010, op. cit., 86. 
outdated census figures of 2001. Interprovincial disputes would add further grist to the abolitionists' mill.

Finally, the conventional wisdom that a crisis is also an opportunity that should not be wasted, applies equally to provinces and local government. ${ }^{100}$ Something positive may come out the crisis for sub-national governments if they can show initiative within the confines of their limited constitutional space. There have been suggestions of how provinces can make a difference around the edges of economic policy by using their revenue more strategically and smarter. ${ }^{101}$ Drawing on the Barcelona Principles, developed by cities and regions across the world in response to the global financial crisis, it has been suggested that Gauteng need to work cooperatively with local government to shape economic strategy for that province. For the Gauteng the mantra is thus "collaborate locally and compete globally." 102 For other cities and regions a more cooperative approach may also pay a dividend in making a difference in the battle against poverty.

\begin{abstract}
This paper examines the impact of the global financial crisis on South Africa, in particular on how the highly centralized federal system absorbed and responded to the crisis. The arguments are that the global crisis and the recession that followed have exacerbated long-standing structural problems in the economy, and that the state's response to the crisis again highlighted the highly centralised nature of the country's fiscal constitution.

One section of the paper explores the impact of the financial crisis on the economy and the three orders of government. Another section examines how each sphere responded to the crisis. A final section assesses the impact of those responses on the political economy of the country and the workings of the federal system, concluding with a speculation on the long term legacy of the global crisis.
\end{abstract}

\title{
Résumé
}

Cet article étudie l'impact de la crise financière globale en Afrique du Sud, et en particulier comment un système fédéral très centralisé a intégré la crise et lui a répondu. Les auteurs soutiennent que la crise globale et la récession qui a suivi ont exacerbé des problèmes structurels économiques de longue date, et que la réponse de l'État à la crise a une fois de plus souligné la nature fortement centralisée de l'organisation financière du pays.

Une section de l'article explore l'impact de la crise financière sur l'économie et sur les trois niveaux de gouvernement. Une autre section étudie comment chaque niveau a répondu à la crise. Une dernière section évalue l'impact de ces réponses sur l'économie politique du pays et le fonctionnement du système fédéral, en concluant par une hypothèse sur les conséquences à long terme de la crise globale.

100. Everatt, David et al, 2009, op. cit.,11.

101. Everatt, David et al, 2009, op. cit., 4.

102. Everatt, David et al, 2009, op. cit., 6. 